\title{
GROUNDWATER RECHARGE ASSESSMENT IN THE KARST AQUIFERS OF NORTH KHORASAN, IRAN USING APLIS METHOD
}

\author{
OCENJEVANJE NAPAJANJA PODZEMNE VODE V KRAŠKIH \\ VODONOSNIKIH V SEVERNEM HORASANU, V IRANU, \\ Z UPORABO METODE APLIS
}

\author{
Hossein ALEM $^{1 *}$, Akbar Esmaeilzadeh SOUDEJANI ${ }^{2} \&$ Saba Nahas FARMANIEH ${ }^{3}$
}

\begin{abstract}
UDC 556.33:551.44(55)

Hossein Alem, Akbar Esmaeilzadeh Soudejani \& Saba Nahas Farmanieh: Groundwater Recharge Assessment in the Karst Aquifers of North Khorasan, Iran Using APLIS Method

In order to optimize consumption, maintenance and control of underground water, an estimation of the groundwater recharge is highly important. Therefore, this research investigates the aquifers in North Khorasan province using APLIS (Applied Physics Laboratory Ice Station) based on a GIS. For this purpose, several significant hydrogeological parameters affecting groundwater recharge including altitude, slope, lithology, soil type and infiltration are considered. Therefore, corresponding layers for these parameters were provided and prioritized. In the end and after integrating the data, the recharge rate was measured qualitatively and different regions were mapped accordingly. The results indicate that the annual average values on a 30-year timescale in karst formations of the North Khorasan vary between $103 \mathrm{~mm}$ and $362 \mathrm{~mm}$, with the mean value of $192 \mathrm{~mm}$. Minimum, maximum and mean recharge rates of aquifer in the study area are $42 \%, 73 \%$ and $54 \%$, respectively. Also, aquifer recharge potential in $83 \%$ of the karst formations is moderate while it is high for the remaining. Low recharge regions correlate to lower karst limestone and dolostone areas in the lower altitudes while high recharge regions represent upper karst limestone and dolostone areas, especially in the high altitudes.
\end{abstract}

Key words: Groundwater resource management, Recharge, APLIS, GIS, karst, North Khorasan.

\author{
Izvleček \\ UDK 556.33:551.44(55) \\ Hossein Alem, Akbar Esmaeilzadeh Soudejani \& Saba Nahas \\ Farmanieh: Ocenjevanje napajanja podzemne vode v kraških \\ vodonosnikih $v$ severnem Horasanu, $v$ Iranu, $z$ uporabo me- \\ tode APLIS
}

Za optimizacijo porabe, vzdrževanja in nadzora nivoja podzemne vode je ocena napajanja vodonosnika zelo pomembna. Zato raziskava $\mathrm{z}$ uporabo metode APLIS, ki temelji na GIS, raziskuje vodonosnike v provinci Severni Horasan v Iranu. Pri tem smo upoštevali več pomembnih hidrogeoloških parametrov, ki vplivajo na napajanje vodonosnika, vključno z nadmorsko višino, naklonom, litologijo, tipom tal in infiltracijo. Za vsakega od parametrov smo pripravili informacije v ustreznih oblikah. Po obdelavi in integraciji podatkov smo izračunali hitrost polnjenja vodonosnika. Različne regije smo ustrezno ovrednotili. Rezultati kažejo, da se v kraških formacijah Severnega Horasana letne povprečne vrednosti v 30-letnem časovnem obdobju gibljejo med $103 \mathrm{~mm}$ in $362 \mathrm{~mm}$, s povprečno vrednostjo $192 \mathrm{~mm}$. Najmanjše, najvišje in povprečne stopnje polnjenja vodonosnika $\mathrm{v}$ študijskem območju so 42-, 73- in 54-odstotne. Tudi potencial polnjenja vodonosnika je v 83-odstotnih kraških formacij ocenjen kot zmeren, za preostale predele je ocenjen kot visok. Območja z nizkim potencialom polnjenja so povezana $\mathrm{z}$ nižje ležečimi zakraselimi apnenci in dolomiti, višje ležeča območja predstavljajo apnenci in dolomiti $\mathrm{z}$ višjim potencialom polnjenja.

Ključne besede: upravljanje podzemnih vodnih virov, napajanje, APLIS, GIS, kras, Severni Horasan.

\footnotetext{
${ }^{1}$ Department of Earth Sciences, College of Sciences, Shiraz University, Shiraz, Iran, e-mail: hosseinalem22@gmail.com

${ }^{2}$ Department of Earth Sciences, College of Sciences, Shiraz University, Shiraz, Iran, e-mail: akbar.esmaeilzadeh@gmail.com

${ }^{3}$ Department of Mathematics, Faculty of Sciences, University of Shiraz, Shiraz, Iran, e-mail: sabafarmanieh@chmail.ir

* Corresponding Author
}

Received/Prejeto: 06.11.2016 


\section{INTRODUCTION}

The increasing population and considerable agricultural and industrial activities, which play a prominent role in the intense decline of aquifer levels, have increased the demand for fresh water. Since the resources are limited, proper maintenance and control on the one hand and appropriate consumption on the other hand require a comprehensive management (Esmaeili \& Moore 2012; Nematollahi et al. 2016). The study and management of karst formations are significant due to their profusion and potential in the creating underground aquifers. The recharge rate is one of the basic parameters in consumption management and maintenance of these resources (Hartmann et al. 2014). Recharge of an aquifer can be defined as the annual average volume that is usually in the form of resources or the average annual input as well as a percentage of precipitation commonly known as 'rate of recharge' or 'effective infiltration' (Mejías et al. 2012; Andreo et al. 2008).

The measured time series of groundwater levels have often been used to quantify the recharge against time (Scanlon et al. 2002) but the heterogeneity of karst rocks in karst areas makes this method insufficient (Bakalowicz 2005).

Methods based on GIS, which utilize geographic attributes of parameters such as geology, altitude, slope, soil type, vegetation and mean annual precipitation, are often applied in order to determine the spatio-temporal distribution of recharge of karst formation (Andreo et al. 2008; Allocca et al. 2014). In this regard, calculation of recharge through conventional methods (evapotranspiration, natural, chemical or synthetic isotopic tracing, and calculation of precipitation against time) or through numerical models has limitations such as lack of access to accurate and periodic data (Radulovic et al. 2012). In the area under study, due to the lack of periodic assessment of the discharge of large springs, such methods produce limitations and problems in calculation of recharge (Guardiola-Albert et al. 2015). Recent years showed significant improvements in assessment methods which are in direct relation to GIS software and many researchers have used these methods (Jyrkama \& Sykes 2007; Scibek \& Allen 2006; Marechal et al. 2006; Lee et al. 2006; Samper et al. 2005; Conrad et al. 2004; Tapia Silva \& Mora Flores 2004; Peña \& Arcos 2004; Bouraoui et al. 1998; Burke 1995). These methods make the calculation of groundwater recharge easier through a quicker and more concise analysis (Peña \& Arcos 2004). In this context and in order to overcome the problems and achieve a more realistic estimation of recharge in karst environment, based on indigenous variables of the aquifer, the Geological Survey of Spain
(IGME) has used a new technique called APLIS (Altitude, Pendant or Slope, Lithology, Infiltration, Soil) (Andreo et al. 2008). Comparatively better than previous models, this method does not require accurate and periodic data and therefore significantly decreases the costs of water resource management (López-Geta et al. 2004). Also, this method allows for the mapping of the spatial distribution of spontaneous recharge of the aquifers in the area (Espinoza et al. 2015). On the other hand, the precise study of autogenic recharge in carbonate rocks (including direct recharge, local and centralized recharge through shallow pits, and even indirect recharge through the substrate of surface water), as well as determination of the annual recharge of groundwater in karst formations are the advantages of APLIS method (Martos-Rosillo 2015). This method can be considered a new branch of recharge calculation study with mathematical expressions and can be called the technique for aquifer recharge calculation using remote testing and GIS (Andreo et al. 2008). This method doesn't have the problems common in conventional methods because the infiltration is studied by attending to the inherent properties of a karst aquifer (such as altitude, slope, lithology, infiltration and soil type). The APLIS index has specifically been used in eight aquifers in Spain where the results were consistent with the standard recharge rate (Andreo et al. 2015). However, this method has been applied in other carbonate aquifers around the world such as Southeast Spain (Touhami et al. 2013; Aguilera \& Murillo 2009), Greece (Zagana et al. 2011), Cuba (Farfán et al. 2010), northeastern Oman (Gerner et al. 2012), the Mediterranean (Hartmann et al. 2014), Southern Spain (Martos-Rosillo et al. 2008) and has achieved successful results.

Given the extent of upper Jurassic and lower Cretaceous Limestone in the cities of Shirvan, Bojnord, Faruj, Safiabad and Moshkan and the expansion of karst in these areas, potential aquifers with abundant fractures and fissures have been created in hard carbonate formations. The discharge of local springs has significantly decreased in recent years and a comprehensive study in these karst zones seems necessary, given their significant role in provision of water used for drinking and agriculture in North Khorasan, especially Shirvan - Asfrayn area. Given the significance of the recharge amount and diversity in discharge of water resources in the area, this study aimed to estimate the annual recharge rate of groundwater in karst formations, including those within cities of Shirvan, Bojnord, Faruj, Safiabad and Moshkan on a scale of 1:100000. 


\section{GEOLOGICAL AND GEOGRAPHICAL SETTING}

\section{GENERAL CHARACTERISTICS OF THE AREA}

The area under study is located between eastern latitudes $56^{\circ} 56^{\prime}$ to $58^{\circ} 30^{\prime}$ and northern longitudes $36^{\circ} 51^{\prime}$ to $37^{\circ} 30^{\prime}$ (Fig. 1). Morphologically, this area includes both plains and mountains, with the lowest point at an altitude of about 928 meters. The height points of the area include a wider range from the north-west to south-east, with a maximum altitude of 3026 meters above the sea level. With an altitude of 1095 meters above the sea level, Shirvan city is located at the center of the area under study. In terms of weather, the northern half of the area has mild and relatively humid summers and relatively cold winters while summer heat does not exceed $40{ }^{\circ} \mathrm{C}$. Due to proximity to Esfaraien plain, the southern half of the area has relatively warm and dry summers, so that during summer the heat reaches to $45^{\circ} \mathrm{C}$. The mean annual precipitation is $275 \mathrm{~mm}$. Average temperatures in April and May 2015 have been reported $10.3{ }^{\circ} \mathrm{C}$ and $18.2^{\circ} \mathrm{C}$, respectively, which, compared to the previous year, are cooler although compared to a long-term statistical period, they're warmer. Based on different methods and classifications, the area under study is semi-arid, with cold winters.

\section{GEOLOGICAL AND STRUCTURAL FEATURES OF THE AREA}

Structurally, the area under study belongs to Kopet Dag and Binalud structural zones, except for a small section in the southeast corner of the area that is located in central Iran. Due to a compression stress, this area stretches over a north-northeast and south-southwest direction. That stress is first visible in shortening and folding, creating thrust faults in some areas as pressure rises (Shabanian et al. 2010). Most of these faults are strike-slip faults with dumping and sometimes normal components; however, a number of thrust faults have been identified with wrinkling and much older than strike-slip faults (Ramazani Oomali et al. 2008).

The geological formations of the area (Fig. 2; Tab. 1) date back to the second period, the Neogene period in tertiary, and the Quaternary (i.e. Kopet Dag zone). From the various lime sets, karst springs such as Golian, Khosravieh, Garmab, Zoeram, Chehel Cheshme, Beshori, Vali Beik, Samand Devin Solocheshme and Starkhihave have outcropped. Deposition of the Paleozoic and Triassic is found in the southern half of the plate in the Binalood zone but the deposition at both Kopet Dag and Binalud continued steadily since the development of the Jurassic

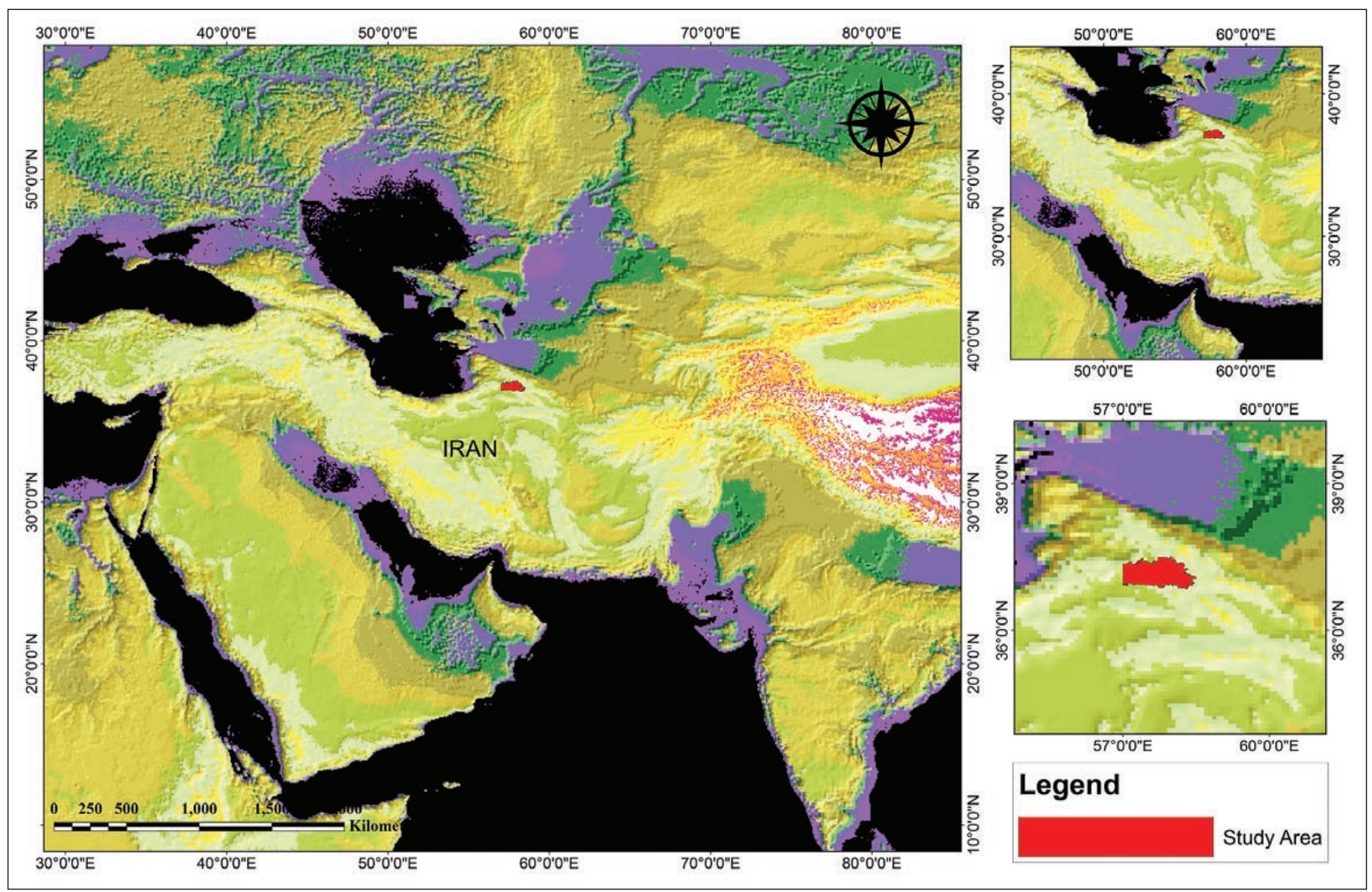

Fig. 1: Geographical location of the study area. 


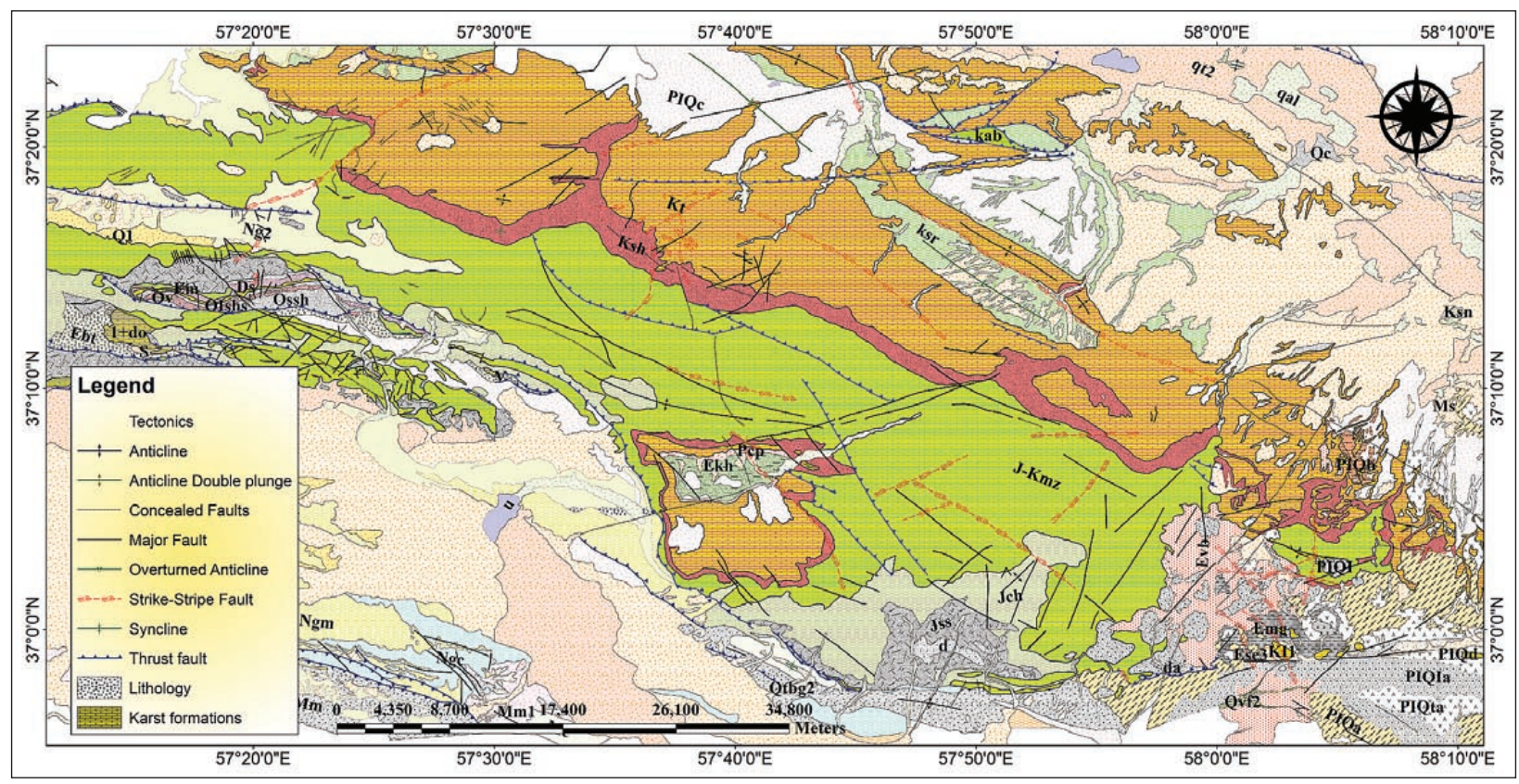

Fig. 2: Geological map of North Khorasan on a scale of 1:100000 (based on geological map of Shirvan, Bojnord, Faruj, Safiabad and Moshkan on a scale of 1: 100,000 at the National Geological Institution of Iran).

Tab. 1: The altitude variable and scoring.

\begin{tabular}{l|c|c|c|c|c|c}
\hline Value & 5 & 6 & 7 & 8 & 9 & 10 \\
\hline Elevation $(\mathrm{m})$ & $900-1200$ & $1200-1800$ & $1800-2100$ & $2100-2400$ & $2400-2700$ & $2700-3100$ \\
\hline
\end{tabular}

Sea up until the end of Cretaceous. Therefore no considerable difference between depositions related to the Jurassic and Cretaceous on the Kopet Dag and Binalud can be observed (Moussavi-Harami \& Brenner 1992), so much so that field observations suggest that outcropped formations of Binalud Paleozoic stretch under Kopet Dag as well. What follows is a brief account of the characteristics of lithology units in the area under study.

\section{HYDRO-GEOLOGICAL FEATURES OF THE AREA}

The karst zone of the area under study is located east of the North Khorasan. The relatively good precipitation, potential carbonate formations such as Tiregan, Mozdvaran, Tizkuh, Mila, Khoshyeilagh and Abderaz, and active tectonics responsible for plenty of fissures and fractures, have been effective in creating the large aquifers of the area. Calcareous zones have covered an area of 1810 square kilometers. Karst springs such as Starkhy, Beshori, Khosravieh, Zoeram, Solocheshme, Garmab, Vali Beik, Golian, Samand Devin and Chehel cheshme have outcropped of these karst zones. According to existing statistics (2003-2014), the average discharge of the 6 karst springs that originate from these calcareous zones is $49.0 \mathrm{~m}^{3} / \mathrm{s}$ while Starkhy and Solocheshme, the largest springs of this karst zone, emit $179.0 \mathrm{~m}^{3} / \mathrm{s}$ and $108.0 \mathrm{~m}^{3} / \mathrm{s}$, respectively. In the area under study, Barzoo River is the main source of groundwater recharge. The river flows from northern heights of Shirvan and through Shirvan city to unite with Atrak River. Thus, this river plays an essential role in recharging underground aquifers in Shirvan plain. The other river is Atrak which originates from the Hezar-masjed, Aladagh and Binalud mountains and lies northwest to the area. The present underground aquifers includes Esfarayen aquifer (which covers large parts in southwest of the area under study and is hydraulically connected with Cal Shour and Cal Jelogir rivers), the southern Safiabad aquifer (which is located in south of the study area and has a hydraulic connection with Cal Shour), the north Safiabad aquifer (which is located in south of the area under study and is hydraulically connected with Esfarayen aquifer, as well as Ab Karane, Cal Shoon and Ab Haragh rivers), and finally, the Quchan aquifer in Shirvan (which is located in the northeastern of the area under study and is hydraulically connected with Atrak and Chery rivers). The aquifer in Shirvan city through the eastern end of the plain has a relatively good qualify for irrigation and is of sodium sulfate type. 


\section{METHODS}

The APLIS method has been applied to estimate the mean infiltration into the carbonate aquifer of precipitation for 30 years and to study the geographical distribution and expansion of karst developments. This method requires a mathematical statement that could stand for a hybrid or superposition layer (Syndepositional) in terms of the main variables of infiltration, since recharge is a result of the physical characteristics of the aquifer. These variables do not have the same weight or importance in recharge. Therefore, the information layers of each variable have been valued according to the ranking system of APLIS and have been combined by using the method equation of APLIS (Andreo et al. 2008) to determine the weight of each variable. Various multidisciplinary approaches including regression analysis (least squares linear fitting), ideal spot analysis, and linear weighted sum method have been used to determine the weight of each variable. The recharge rate can be calculated by combining the inherent variables of each aquifer such as the altitude above the sea level, slope, lithology, infiltration, and type of soil.
The total mean recharge rate of an aquifer can be calculated by entering information layers of each variable into GIS software environment using Equation 1 below, also known as APLIS index of recharge (Andreo et al. 2008).

$\mathrm{R}=(\mathrm{A}+\mathrm{P}+3 \times \mathrm{L}+2 \times \mathrm{I}+\mathrm{S}) / 0.9$

In this equation (Eq. 1), $\mathrm{R}$ represents the mean rate recharge, A: altitude, P: Pendant or Slope, L: Lithology, I: Preferential infiltration, and S: Soil type. The weight of each variable in the equation demonstrates their importance in determining the recharge rate (Duran et al. 2004). So, the lithology variable is three times more effective than the altitude (above the sea level), slope and soil whereas the variable of preferential infiltration in the areas is twice more effective than the mentioned variables. When divided by 0.9 , the recharge rate from the precipitation on the surface of aquifer is about 8.88 to $88.8 \%$. In other words, recharge happens all the time, although this amount never reaches $100 \%$ of precipitation.

\section{RESULTS AND DISCUSSION}

The mean recharge rate $(\mathrm{R})$ for every aquifer is the average values of $\mathrm{R}$ corresponding to spatial units in the recharge map. In this scheme, there are ten rankings for each variable while each ranking is scored in an arithmetic progression of 1 to 10 (Andreo et al. 2008). Points 1 and 10 indicate minimum and maximum effective infiltration, respectively. In the following, the generated layers in this method are described.

\section{INFORMATIONAL VARIABLES Altitude variable}

The $5 \mathrm{~m}$-DEM of area was produced in GIS Software using data from AutoCAD (such as altitude points, canals, elevation points and fracture of the area under study). Then this map was introduced to software and after the operation, the altitude map was extracted as output. The altitude variable was classified in ten sequences at intervals of $300 \mathrm{~m}$ (Tab. 1) and scores of 1 to 10 assigned to each ranking (Andreo et al. 2008). Given the minimum altitude of the area under study $(919.4 \mathrm{~m})$, this variable was ranked in 6 sequences (scores from 5 to 10). Given that a major portion of the area is located at high altitude, high points represent them so that point 10, for example, is prevailing in the area under study (Fig. 3). The produced layer for this variable and scores of each sequence show that with larger altitude, the precipitation increases, leading to greater aquifer recharge. Also, difference between recharge amounts of altitude higher than 3,100 AMSL is not significant.

\section{Slope variable}

The map of slopes in the area under study was produced in GIS software using the existing slope data obtained from the National Geological Institution of Iran with scale of 1:100000 and then was ranked in 9 different sequences (Tab. 2). In the scoring system, point 7 was removed. Rating of slope at irregular intervals was done in accordance with the classification used in Andalusia Environmental Information System, where the slope is divided into 9 categories and point 7 is deleted from the slope table (Andreo et al. 2008). The scores assigned to the slope parameters decrease as slope gets steeper which means that increase in slope leads to decrease in groundwater recharge (Fig. 3). Therefore, low areas with a minimum slope get the highest scores (i.e. score 10). At heights, the slope is mainly between 3, 4 and 5 and rarely larger than this.

\section{Lithology variable}

Based on field observations and stratigraphic studies for the lithology variable, calcareous formations of Mozdu- 


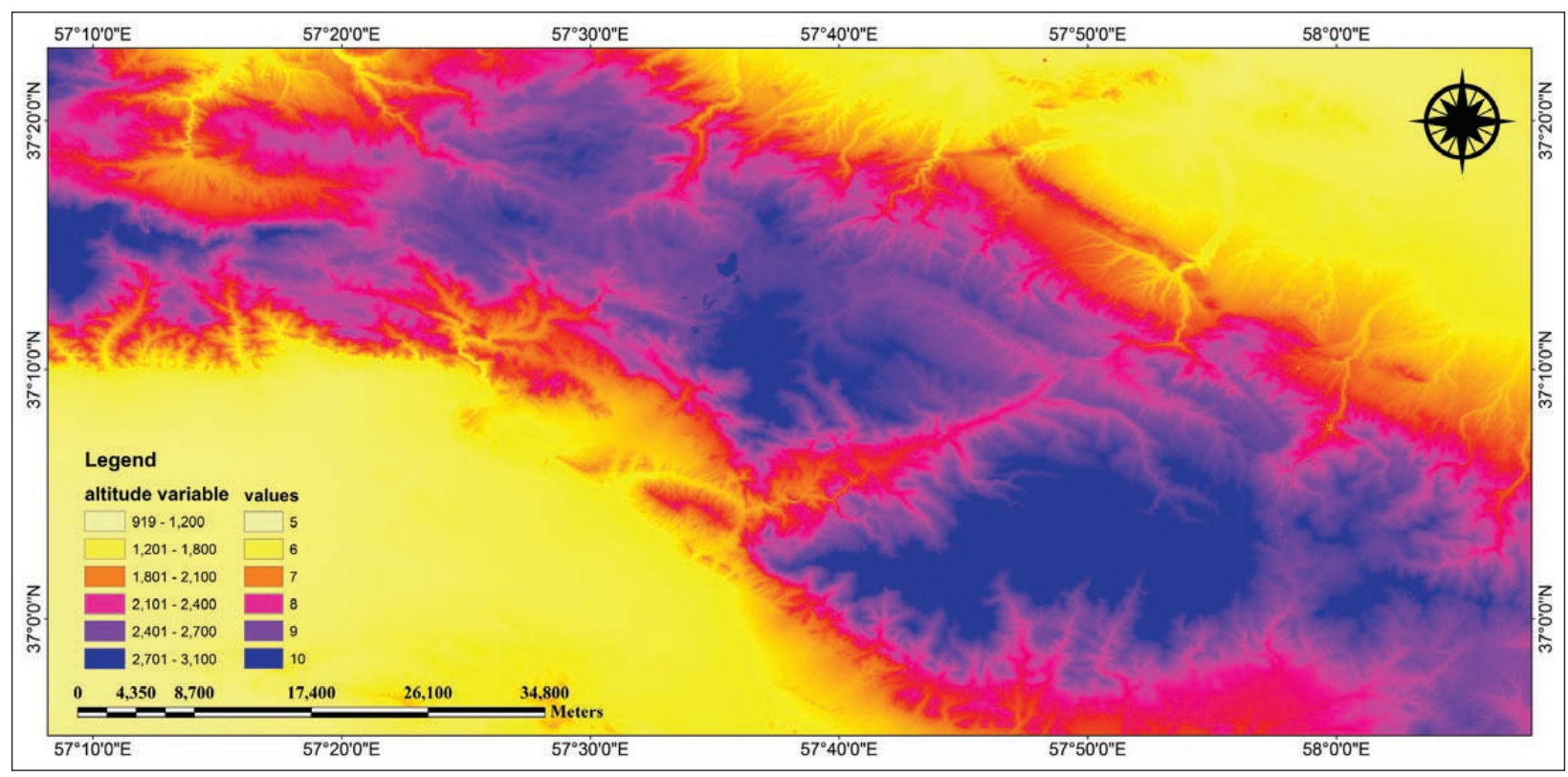

Fig. 3: The altitude map and values of the layers.

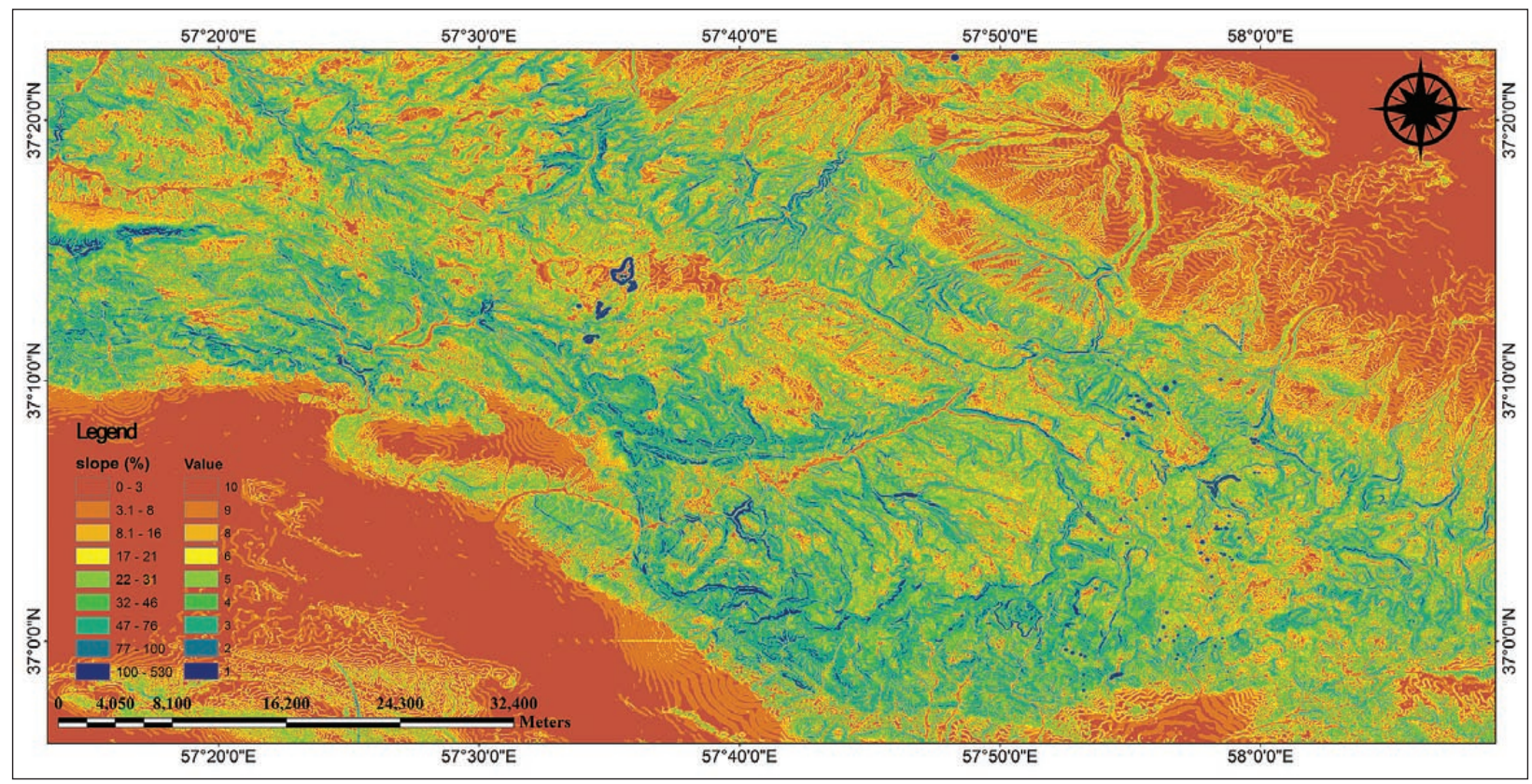

Fig. 4: The slope map and the slope values.

Tab. 2: The slope variable and scoring.

\begin{tabular}{l|c|c|c|c|c|c|c|c|c}
\hline Value & 1 & 2 & 3 & 4 & 5 & 6 & 8 & 9 & 10 \\
\hline Slope (\%) & $100<$ & $76-100$ & $46-76$ & $31-46$ & $21-31$ & $16-21$ & $8-16$ & $3-8$ & $3 \geq$ \\
\hline
\end{tabular}

aran, Lar and Tiregan (the original lime formations in the area) are made of bright pink lime, dolomitic lime, brown orbitolina lime and reef lime with marl interlayer that are distinguished by having many fissures. Accordingly and taking into account these observations, point
8 was determined for the areas covered with limestone. Therefore, as shown below (Tab. 3) limestone and fissured, fractured and partly karsted dolomite will be considered as the dominant rock formations in the area. 


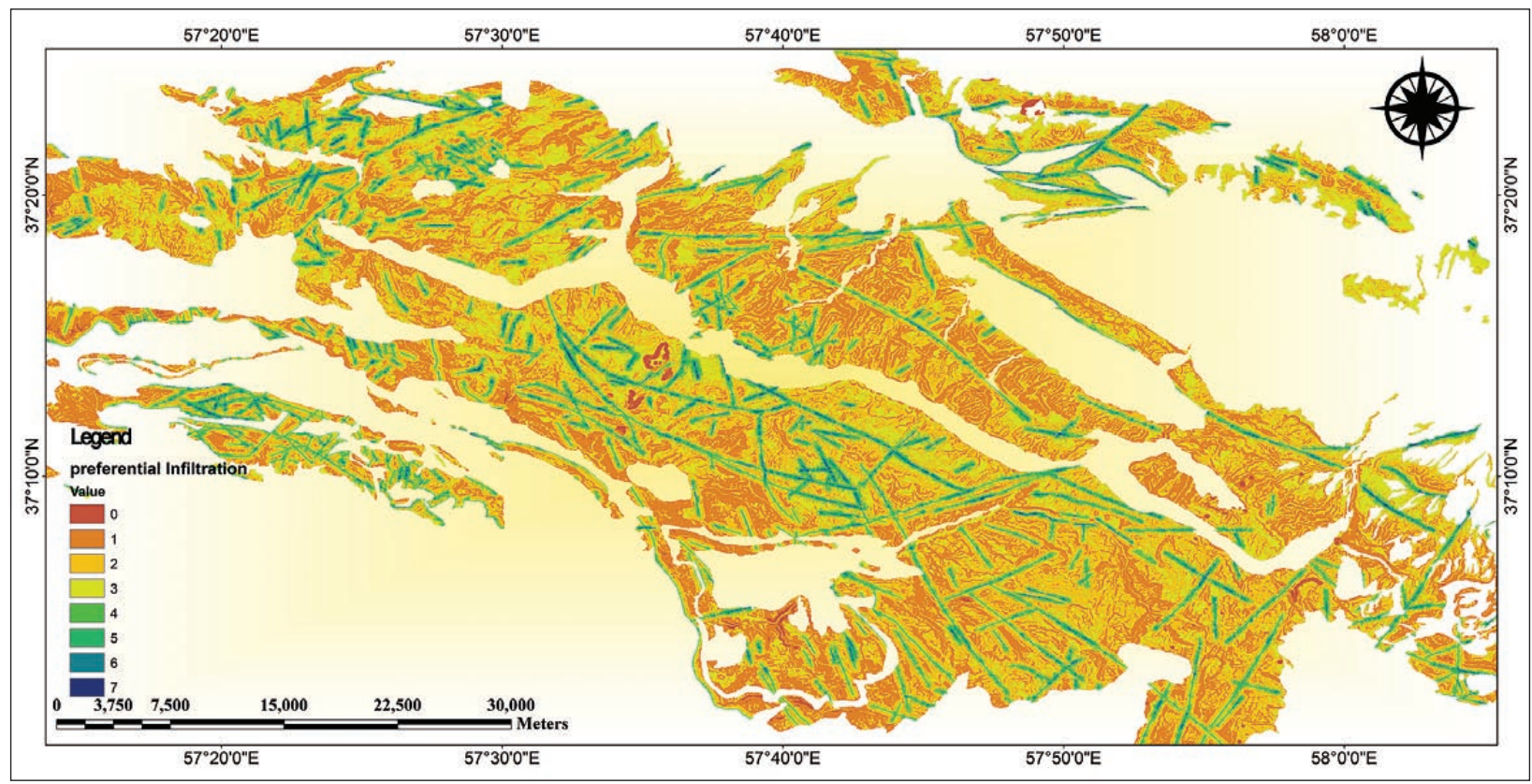

Fig. 5: Map of preferential Infiltration of areas.

Tab. 3: The lithology variable and scoring of this variable.

\begin{tabular}{l|l}
\hline Value & Lithology variable \\
\hline $9-10$ & Limestone and karst dolomite \\
\hline $7-8$ & $\begin{array}{l}\text { Limestone and fissured and fractured and partly karst } \\
\text { dolomite }\end{array}$ \\
\hline $5-6$ & Limestone and fissured and fractured dolomite \\
\hline 4 & Sand and Gravel \\
\hline 3 & Conglomerate \\
\hline 2 & Intrusive and metamorphic rocks \\
\hline 1 & Shale, silt, sand \\
\hline
\end{tabular}

\section{Soil variable}

The classification of different soil types and rating system for these variables are presented in Table 4. Based on field studies, soil in the area is mainly calcareous regosols and fluvisols. Therefore, the point 8 was assigned to the layer of this variable. This type of soil is formed with very low thickness on hard formations and classified as poorly evolved soils. The thickness of this kind of soil is less than $50 \mathrm{~cm}$.

\section{Preferential infiltration variable}

Ten rankings ranging from 1 to 10 were assigned to Preferential Infiltration variable. Points 1 and 10 are awarded to areas with minimum and maximum Preferential In- filtration, respectively. As mentioned above, this layer is the outcome of three layers: slope, fault and rock type. According to the instruction of APLIS method 10 intervals are considered for the slope variable. That is as it was said; the variable 7 has been deleted. In fact, by increasing the gradient, the Preferential Infiltration variable has increased. Also, three intervals are considered for the fracture variable. Naturally, with increasing distance from junction and fault zones, the level of Preferential Infiltration decreases. In the case of Lithology variable; due to the unitary lithology of karst formations of the region Score 1 will be awarded (Tab. 5). Finally, according to the mean amount found for three layers, preferential infiltration rate was determined for different areas (Fig. 5). Accordingly, the preferential infiltration often occurs in low-slope areas which are made of limestone and normally are characterized by their potential to become karst.

\section{CALCULATION OF THE RECHARGE RATE Qualitative calculation of the recharge rate} In order to estimate the mean rate of aquifer recharge in the area under study, information layers were combined according to the APLIS equation in the GIS environment

Tab. 4: The soil variable and scoring of this variable.

\begin{tabular}{l|l|l|l|l|l|l|l|l|l|l}
\hline $\begin{array}{l}\text { Soil } \\
\text { variable }\end{array}$ & Leptosols & $\begin{array}{l}\text { Arenosols } \\
\text { and } \\
\text { xerosols }\end{array}$ & $\begin{array}{l}\text { Calcareous } \\
\text { regosols } \\
\text { and } \\
\text { fluvisols }\end{array}$ & $\begin{array}{l}\text { Euthric } \\
\text { regosols } \\
\text { and } \\
\text { solonchaks }\end{array}$ & Cambisols & $\begin{array}{l}\text { Euthric } \\
\text { cambisols }\end{array}$ & $\begin{array}{l}\text { Histosols } \\
\text { and } \\
\text { luvisols }\end{array}$ & $\begin{array}{l}\text { Chromic } \\
\text { luvisols }\end{array}$ & Planosols & Vertisols \\
\hline Value & 10 & 9 & 8 & 7 & 6 & 5 & 4 & 3 & 2 & 1 \\
\hline
\end{tabular}




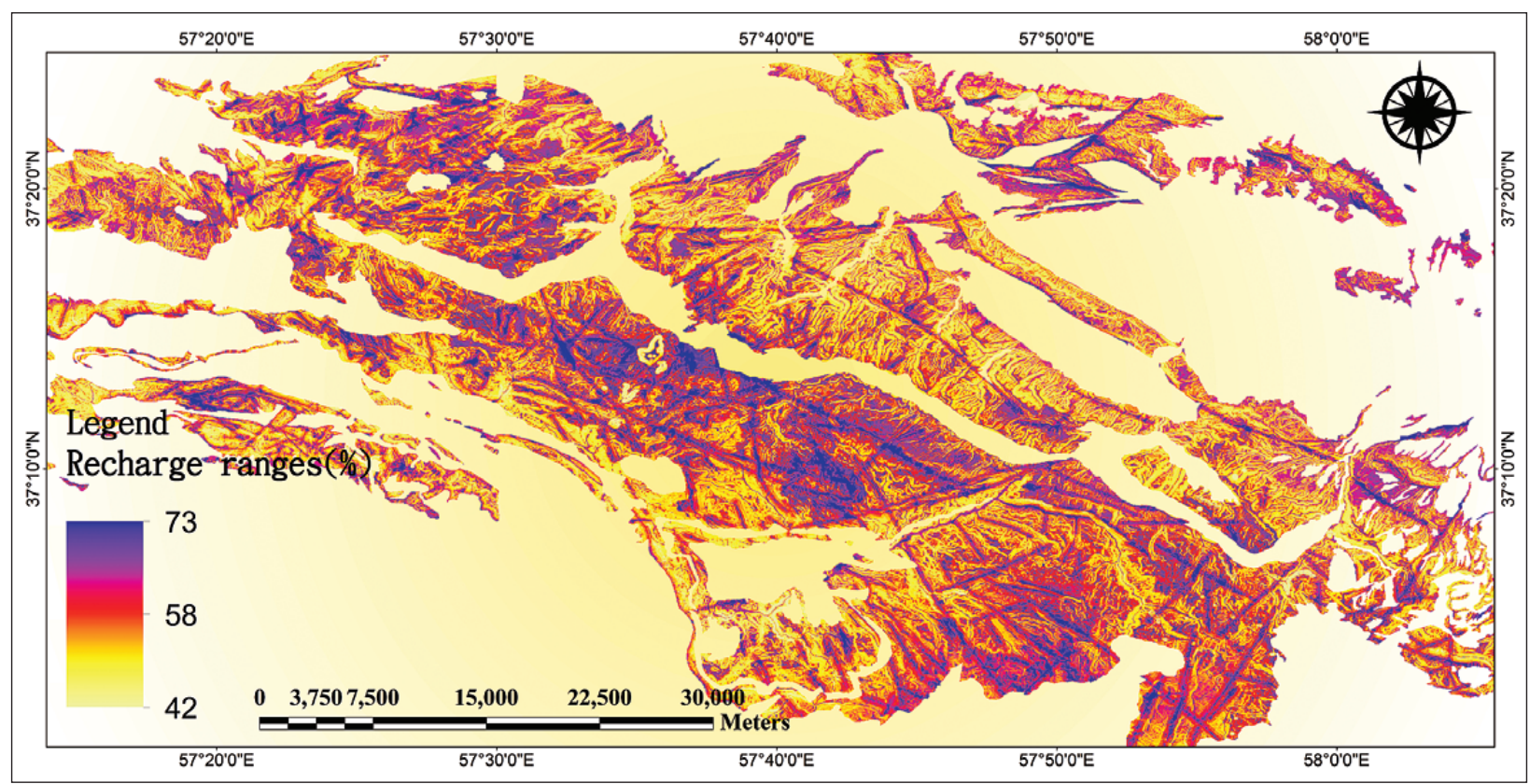

Fig. 6: Map of the recharge rate estimation using the APLIS method in the study area.

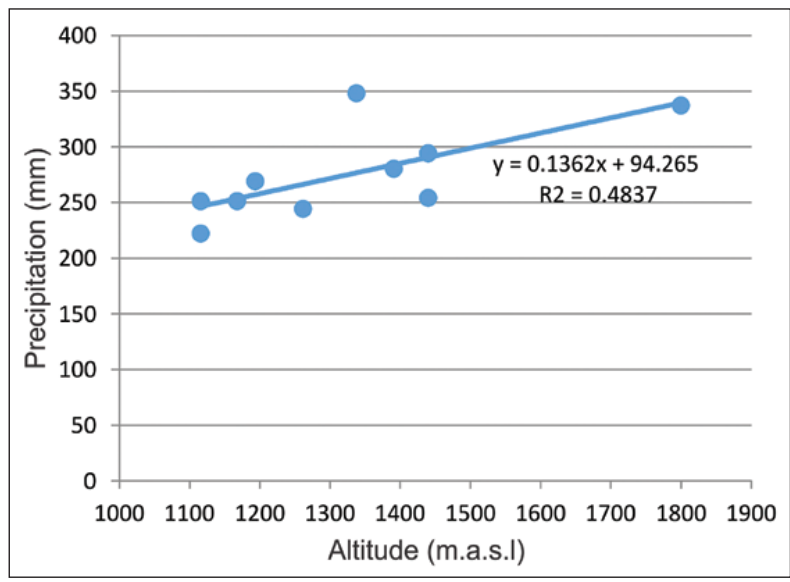

Fig. 7: The altitude-precipitation relationship in the area under study.

(Fig. 6). Based on the calculations, minimum, maximum and mean recharge rate in aquifers under study were
$42 \%, 73 \%$ and $54 \%$, respectively. Spatially, the mean recharge rate obtained from APLIS in this study (54\%) is in compliance with other studies in different regions with a recharge rate of $32 \%$ - $54 \%$ (Andreo et al. 2008).

The results show that $83 \%$ of karst formations in North Khorasan have moderate recharge and remaining $17 \%$ shows high recharge (Tab. 6).

Low-recharge areas have a very good correlation with the areas at lower altitudes that have no karst formations in limestones. Areas with sufficient recharge associated with karst in the limestone and dolomite are shown below. Also, areas with high recharge are located in the vicinity of the main springs of Shirvan. In these areas, recharge rate increases in proportion to altitude. Such an association seems logical since higher areas have less soil thickness and therefore have more diverse vegetation. Therefore, less water is lost to evaporation and transpiration (evapotranspiration). Equally important is the water from sinkholes that plays an important role in

Tab. 5: The preferential infiltration variable and scoring of this variable.

\begin{tabular}{l|l|l|l|l|l|l|l|l|l|l|l|l|l|l}
\hline $\begin{array}{l}\text { Variable } \\
\text { slope } \\
(\%)\end{array}$ & $\leq 3$ & $8-3$ & $8-16$ & $21-16$ & $31-21$ & $46-31$ & $76-46$ & $100-76$ & $100<\begin{array}{l}\text { Distance from } \\
\text { the main } \\
\text { fracture (m) }\end{array}$ & $\leq 50$ & $150-50$ & $300-150$ & Lithology \\
\hline Value & 10 & 9 & 8 & 6 & 5 & 4 & 3 & 2 & 1 & Value & 10 & 6 & 2 & 1 \\
\hline
\end{tabular}

Tab. 6: Different recharge ranges used to draw the map of spatial distribution of recharge.

\begin{tabular}{l|c|c|c|c|c}
\hline Different recharge ranges (\%) & $\leq 20$ & $20-40$ & $40-60$ & $60-80$ & $\geq 80$ \\
\hline Recharge & very low & low & moderate & high & very high \\
\hline
\end{tabular}




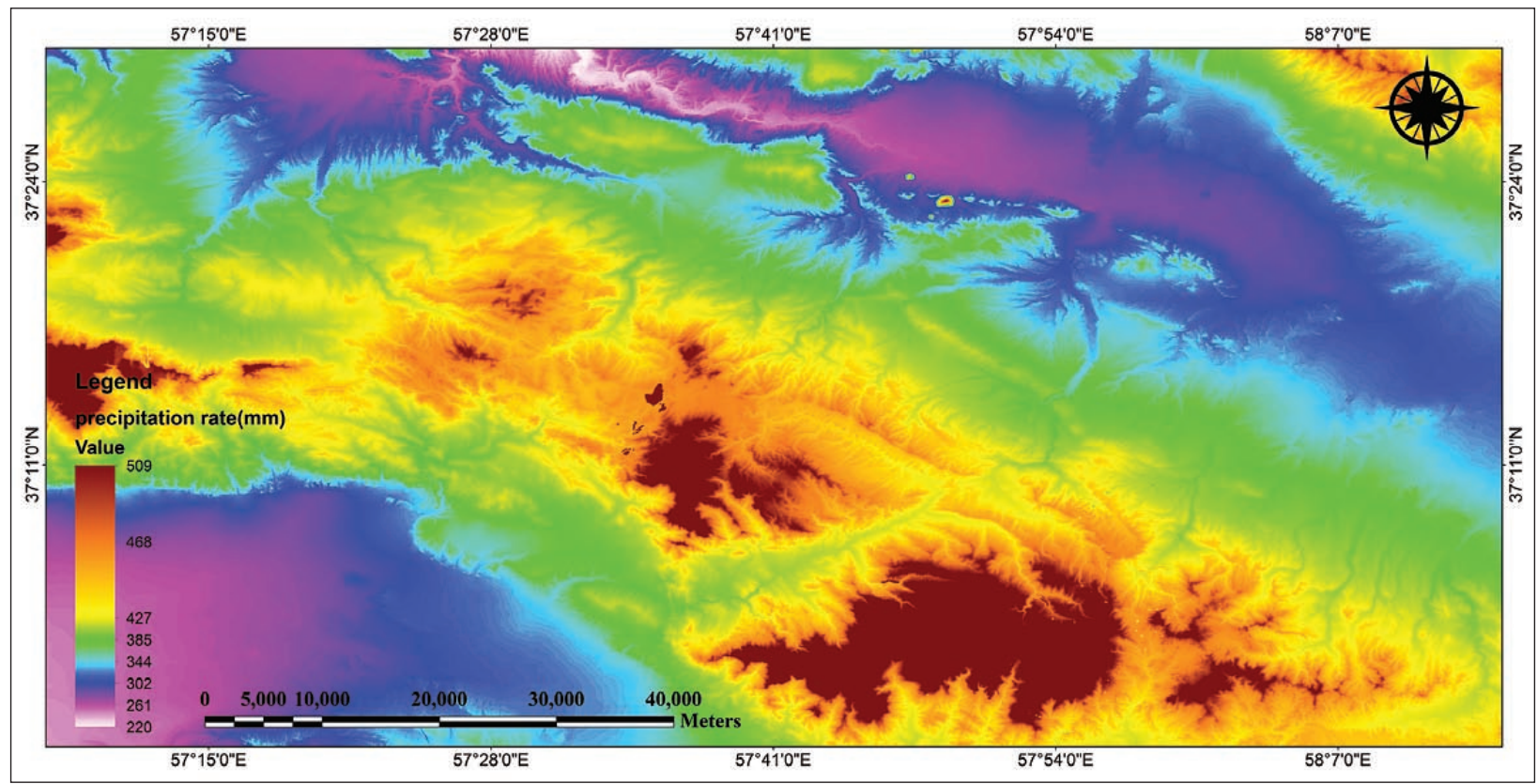

Fig. 8: Map of precipitation rate of area under study.

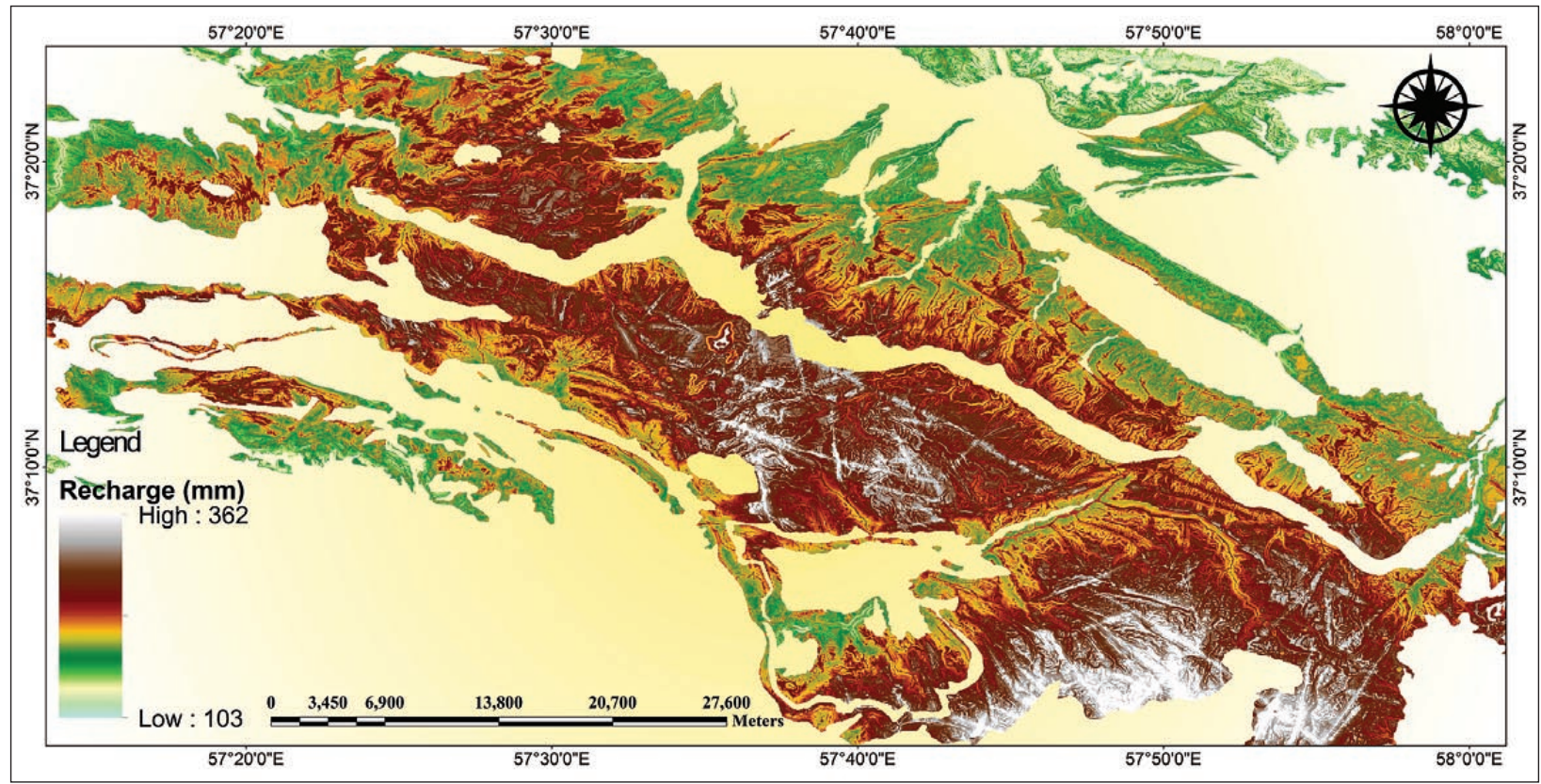

Fig. 9: Map of the mean annual recharge rate in the karst formations in a 30-year period.

recharge rate in low areas. So, the presence of water of sinkholes in low-altitude areas may be responsible for altitude-specific differences in recharge.

\section{Quantitive calculation of the recharge rate}

Based on the mean precipitation over a span of 30 years from rain-gauging stations in the area (Tab. 7) and on the altitude of each station, Precipitation-Altitude Graph was plotted (Fig. 7). Equation 2 is obtained from the fit of these points.

$Y=0.1349 \mathrm{X}+96.028$

In this regard, $\mathrm{X}$ stands for altitude variable, and $\mathrm{Y}$ stands for the precipitation variable based on the altitude. After putting the equation in GIS software and introducing variable $\mathrm{X}$ as altitude $\mathrm{DEM}$, variable $\mathrm{Y}$ was given as 
Tab. 7: Information from Rain-Gauging Stations of North Khorasan.

\begin{tabular}{l|c|c|c|c|c}
\hline Station name & River name & $Y$ & $X$ & Elevation & Precipitation rate $($ mm $)$ \\
\hline Chery & Chery & 371037 & 580909 & 1338 & 348 \\
\hline Seiek ab shirvan & Atrak & 372451 & 575556 & 4401 & 254 \\
\hline Asadly & Atrak & 371731 & 572134 & 1800 & 337 \\
\hline Beshghardash & Atrak & 372440 & 571706 & 1116 & 251 \\
\hline Farug & Atrak & 371410 & 581310 & 1194 & 269 \\
\hline Shurak & Shurak & 372233 & 574143 & 1168 & 251 \\
\hline Bidovaz esfaraien & Esfaraien & 370403 & 573034 & 1262 & 244 \\
\hline Rubin araghi & Araghi & 371115 & 572522 & 1391 & 280 \\
\hline Khosh esfaraien & Calshur jajrom & 370747 & 572026 & 1116 & \\
\hline Nushirvan & Bidovaz & 370437 & 573622 & 1440 & 222 \\
\hline
\end{tabular}

DEM output for precipitation rate in the area with accuracy of 5 meters (Fig. 8). Then using the precipitation DEM and the recharge rate for karst formations in area under study (using APLIS), mean input of precipitation in North Khorasan for 30-year period was obtained in GIS software (Fig. 9). Accordingly, the mean annual recharge rate in the karst formations of Northern Khorasan over a 30-year period is between 103 to $362 \mathrm{~mm}$ with an mean rate of $192 \mathrm{~mm}$ that has a good correlation with increase in altitude. In this way, the mean annual recharge rate is maximum in high karst areas with plenty of fissures and fractures and low-slope.

\section{CONCLUSION}

The APLIS method is applied on a regional scale. The spatial distribution of recharge is determined and main advantage in comparison with conventional methods. But since the recharge map is on a regional scale, it is not realistic to expect a high accuracy and the map should be used cautiously for detailed analyses on a local scale.

Using APLIS method, in this study the spatial distribution of recharge of the karst areas of Shirvan Plain- Esfarayen in North Khorasan was assessed. In this method, which is based on spatial information and positioning, the map of mean recharge rate was based on information layers of altitude, slope, lithology, soil and preferential infiltration zones was developed in GIS software.

The results indicate that the limestone and fissured, fractured and partly karsted dolomite should be considered as the dominant rock formations in the area particularly in low-slope altitudes and areas. The results show that minimum recharge rate in the area under study is $42 \%$, mainly located in karst areas. Low-recharge areas are in a very close correlation with the zones free of karst at lower altitudes. Recharge rate in karst highlands with low slopes and abundant fissures has been determined to be around $73 \%$, a maximum rate. Also, $83 \%$ of karst formations in North Khorasan have moderate recharge while $17 \%$ has a high recharge level. The annual rate of recharge in the karst formations of Northern Khorasan over a 30-year period is between $103 \mathrm{~mm}$ to $362 \mathrm{~mm}$ with a mean rate of $192 \mathrm{~mm}$.

Taking into account the recharge rate in different area of zoning, the proper management measures can be planned in order to conserve and consumption management of water resources. In this way, using water resources in the region would be strictly controlled by the recharge rate of precipitation and especially where recharge rate is low using water resources should be controlled. Proper performance with regard to consumption management is possible with regular supervision of water levels and consumption restrictions with respect to the recharge rate as the sole incoming component in the aquifer. The authors of this study strongly suggest that future studies consider management methods of restricted use considering recharge rate, especially in areas with low recharge. 


\section{REFERENCES}

Aguilera, H. \& J.M. Murillo, 2009: The effect of possible climate change on natural groundwater recharge based on a simple model: a study of four Karst aquifers in SE Spain.- Environmental Geology, 57, 5, 963-974. DOI: https://doi.org/10.1007/s00254-008 $-1381-2$.

Allocca, V., Manna, F. \& P. De Vita, 2014: Estimating annual groundwater recharge coefficient for karst aquifers of the southern Apennines, Italy.- Hydrol. Earth Syst. Sci., 18, 2, 803-817. DOI: https://doi. org/10.5194/hess-18-803-2014.

Andreo, B., Vías, J., Durán, J.J., Jiménez, P., López-Geta, J.A. \& F. Carrasco, 2008: Methodology for groundwater recharge assessment in carbonate aquifers: application to pilot sites in southern Spain.- Hydrogeology Journal,16, 5, 911-925. DOI: https://doi. org/10.1007/s10040-008-0274-5.

Andreo, B., Carrasco, F., Durán, J.J., Jiménez, P. \& J.W. LaMoreaux (eds.), 2015: Hydrogeological and Environmental Investigations in Karst Systems.- Environmental Earth Sciences, Vol. 1, Springer Berlin Heidelberg, pp. 638, Berlin. DOI: https://doi. org/10.1007/978-3-642-17435-3.

Bakalowicz, M., 2005: Karst groundwater: A challenge for new resources.- Hydrogeology Journal, 13, 2, 148-160. DOI: https://doi.org/10.1007/s10040-004 $-0402-9$.

Bouraoui, F., Vachaud, G. \& T. Chen, 1998: Prediction of the effect of climatic changes and land use management on water resources.- Physics and Chemistry of the Earth, 23, 4, 379-384. DOI: https://doi. org/10.1016/S0079-1946(98)00041-X.

Burke, S., 1995: Land surface parameterisation: regionalised versus distributed approach to groundwater recharge.- Physics and Chemistry of the Earth, 20, 331-337. DOI: https://doi.org/10.1016/0079-1946(95)00045-3.

Conrad, J., Nel, J. \& J. Wentzel, 2004: The challenges and implications of assessing groundwater recharge: a case study - northern Sandveld, Western Cape, South Africa.- Water SA, 30, 5, 75-81. DOI: http:// dx.doi.org/10.4314/wsa.v30i5.5171.

Duran, Z., Doğru, A.G. \& G. Toz, 2004: Web-based multimedia GIS for historical sites.- In: Altan, O. (ed.) Geo-Imagery Bridging Continents, Proceedings of the $\mathrm{XX}^{\text {th }}$ ISPRS Congress, $12^{\text {th }}-23^{\text {rd }}$ July 2004, Istanbul, Turkey. ISPRS, Technical Commission V, 434-438, Turkey.
Esmaeili, A. \& F. Moore, 2012: Hydrogeochemical assessment of groundwater in Isfahan province, Iran.Environmental Earth Sciences, 67, 1, 107-120. DOI: https://doi.org/10.1007/s12665-011-1484-z.

Espinoza, K., Marina, M., Fortuna, J.H. \& F. Altamirano, 2015: Comparison of the APLIS and Modified-APLIS Methods to Estimate the Recharge in Fractured Karst Aquifer, Amazonas, Peru.- In: Andreo, B., Carrasco, F., Durán, J.J., Jiménez, P. \& J.W. LaMoreaux (eds.) Hydrogeological and Environmental Investigations in Karst Systems. Environmental Earth Sciences, Vol. 1, Springer Berlin Heidelberg, pp. 83-90, Berlin. DOI: https://doi.org/10.1007/978-3642-17435-3_10.

Farfán, H., Corvea, J.L. \& I. De Bustamante, 2010: Sensitivity Analysis of APLIS Method to Compute Spatial Variability of Karst Aquifers Recharge at the National Park of Viñales (Cuba).- In: Andreo, B., Carrasco, F., Durán, J.J. \& J.W. LaMoreaux (eds.) Advances in Research in Karst Media. Environmental Earth Sciences, Springer Berlin Heidelberg, pp. 19-24, Berlin. DOI: https://doi.org/10.1007/978-3642-12486-0_3.

Gerner, A., Schütze, N. \& G.H. Schmitz, 2012: Portrayal of fuzzy recharge areas for water balance modelling: a case study in northern Oman.- Advances in Geosciences, 31, 1-7. DOI: https://doi.org/10.5194/ adgeo-31-1-2012.

Guardiola-Albert, C., Martos-Rosillo, S., Pardo-Igúzquiza, E., Durán Valsero, J.J., Pedrera, A., JiménezGavilán, P. \& C. Liñán-Baena, 2015: Comparison of Recharge Estimation Methods during a Wet Period in a Karst Aquifer.- Groundwater, 53, 6, 885-895. DOI: https://doi.org/10.1111/gwat.12310.

Hartmann, A., Mudarra, M., Andreo, B., Marín, A., Wagener, T. \& J. Lange, 2014: Modeling spatiotemporal impacts of hydroclimatic extremes on groundwater recharge at a Mediterranean karst aquifer.Water Resources Research, 50, 8, 6507-6521. DOI: https://doi.org/10.1002/2014WR015685.

Jyrkama, M.I. \& J.F. Sykes, 2007: The impact of climate change on spatially varying groundwater recharge in the grand river watershed (Ontario).- Journal of Hydrology, 338, 3-4, 237-250. DOI: https://doi. org/10.1016/j.jhydrol.2007.02.036.

Lee, C.H., Chen, W.P. \& R.H. Lee, 2006: Estimation of groundwater recharge using water balance coupled with base-flow-record estimation and stable-baseflow analysis.- Environmental Geology, 51, 73-82. DOI: https://doi.org/10.1007/s00254-006-0305-2. 
López-Geta, J.A., Andreo, B., Vías, J., Durán, J.J., Carrasco, F. \& P. Jiménez, 2004: Aproximación metodológica para evaluar la recarga en acuíferos carbonáticos. - Instituto geológico y minero de España, Universidad de Málaga, Madrid.

Maréchal, J.C., Dewandel, B., Ahmed, S., Galeazzi, L. \& F.K. Zaidi, 2006: Combined estimation of specific yield and natural recharge in a semi-arid groundwater basin with irrigated agriculture.- Journal of Hydrology, 329, 281-293. DOI: https://doi. org/10.1016/j.jhydrol.2006.02.022.

Martos-Rosillo, S., González-Ramón, A., Jiménez, P., Durán, J.J., Andreo, B. \& E. Mancera-Molero, 2015: Synthesis of Groundwater Recharge of Carbonate Aquifers in the Betic Cordillera (Southern Spain).In: Andreo, B., Carrasco, F., Durán, J.J., Jiménez, P. \& J.W. LaMoreaux (eds.) Hydrogeological and Environmental Investigations in Karst Systems. Environmental Earth Sciences, Vol. 1, Springer Berlin Heidelberg, pp. 91-102, Berlin. DOI: https://doi. org/10.1007/978-3-642-17435-3_11.

Martos-Rosillo, S., Pérez-Fernández, F. \& J.J. Durán, 2008: Estimation of the average annual recharge in the carbonate aquifers of Sierra de Estepa (Seville) using the APLIS method.- Geotemas, 10, 5167-5172.

Mejías, M., Ballesteros, B.J., Antón-Pacheco, C., Domínguez, J.A., Garcia-Orellana, J., Garcia-Solsona, E. \& P. Masqué, 2012: Methodological study of submarine groundwater discharge from a Karst aquifer in the Western Mediterranean Sea.- Journal of Hydrology, 464-465, 27-40. DOI: https://doi. org/10.1016/j.jhydrol.2012.06.020.

Moussavi-Harami, R. \& R.L. Brenner, 1992: Geohistory Analysis and Petroleum Reservoir Characteristics of Lower Cretaceous (Neocomian) Sandstones, Eastern Kopet-Dagh Basin, Northeastern Iran.- AAPG Bulletin, 76, 8, 1200-1208.

Nematollahi, M.J., Ebrahimi, P., Razmara, M. \& A. Ghasemi, 2016: Hydrogeochemical investigations and groundwater quality assessment of Torbat-Zaveh plain, Khorasan Razavi, Iran.- Environmental Monitoring and Assessment, 188, 1. DOI: https:// doi.org/10.1007/s10661-015-4968-6.

Peña, S. \& D. Arcos, 2004: Estimación inicial de la recarga natural vertical para su introducción en modelos de simulación de flujo con la ayuda de sistemas de información geográfica.- Paper presented at the Seminario: Sistematización y automatización como herramienta para la gestión del agua. Guanajuato, pp. 9.

Radulovic, M., Stevanovic, Z. \& M. Radulovic, 2012: A new approach in assessing recharge of highly karstified terrains-Montenegro case studies.- Envi- ronmental Earth Sciences, 65, 8, 2221-2230. DOI: https://doi.org/10.1007/s12665-011-1378-0.

Ramazani Oomali, R., Hafezi Moghaddas, N., Omidi, P. \& J. Eftekharnejhad, 2008: A Model for Active Tectonics in Kope Dagh (North-East Iran).- World Applied Sciences Journal, 3, 2, 312-316.

Samper, F.J., García Vera, M.A., Pisani, B., Alvares, D., Varela, A. \& J.A. Losada, 2005: Modelos hidrológicos y sistemas de información geográfica para la estimación de los recursos hídricos: GIS-BALAN a varias cuencas Españolas.- In: Samper Calvete, F.J. \& A. Paz González (eds.) VII Jornadas de Investigación de la Zona no Saturada del Suelo. Tórculo Artes Gráficas, pp. 269-274, A Coruña.

Scanlon, B.R., Healy, R.W. \& P.G. Cook, 2002: Choosing appropriate techniques for quantifying groundwater recharge.- Hydrogeology. Journal, 10, 1, 18-39. DOI: https://doi.org/10.1007/s10040-001-0176-2

Scibek, J. \& D.M. Allen, 2006: Comparing modelled responses of two high-permeability, unconfined aquifers to predicted climate change.- Global and Planetary Change, 50, 1-2, 50-62. DOI: https://doi. org/10.1016/j.gloplacha.2005.10.002.

Shabanian, E., Bellier, O., Abbassi, M.R., Siame, L. \& Y. Farbod, 2010: Plio-quaternary stress states in NE Iran: Kopeh Dagh and Allah Dagh-Binalud mountain ranges.- Tectonophysics 480, 1-4, 280-304. DOI: https://doi.org/10.1016/j.tecto.2009.10.022.

Tapia Silva, F.O. \& F.E. Mora Flores, 2004: Application of Spatial Analysis in Implementation of a Qualitative Infiltration Model to Evaluate the Aquifer's Potential Recharge for Conservation Areas of Mexico City.- In: Oberweis, A. \& J. Rumble (eds.) The Information Society: New Horizons for Science, $19^{\text {th }}$ International CODATA Conference, $7^{\text {th }}-10^{\text {th }}$ November 2004, Berlin, Germany. CODATA, pp. 13, Berlin.

Touhami, I., Andreu, J.M., Chirino, E., Sánchez, J.R., Moutahir, H., Pulido-Bosch, A., Martínez-Santos, P. \& J. Bellot, 2013: Recharge estimation of a small karstic aquifer in a semiarid Mediterranean region (southeastern Spain) using a hydrological model.- Hydrological Processes, 27, 2, 165-174. DOI: https://doi.org/10.1002/hyp.9200.

Zagana, E., Tserolas, P., Floros, G., Katsanou, K. \& B. Andreo, 2011: First outcomes from groundwater recharge estimation in evaporate aquifer in Greece with the use of APLIS method.- In: Lambrakis, N., Stournaras, G. \& K. Katsanou (eds.) Advances in the Research of Aquatic Environment, Environmental Earth Sciences, Vol. 2, Springer Berlin Heidelberg, pp. 89-96, Berlin. DOI: https://doi.org/10.1007/9783-642-24076-8_11. 